\title{
THE HOMOEOMEROUS PARTS AND THEIR REPLACEMENT BY BICHAT'S TISSUES
}

\author{
by
}

\section{JOHN M. FORRESTER *}

Bichat (1801) developed a set of twenty-one distinguishable tissues into which the whole human body could be divided. ${ }^{1}$ This paper seeks to distinguish his set from its predecessor, the Homoeomerous Parts of the body, and to trace the transition from the one to the other.

The earlier comparable set of distinguishable components of the body was the Homoeomerous Parts, a system founded according to Aristotle by Anaxagoras (about $500-428 \mathrm{BC}){ }^{2}$ and covering not just the human body, or living bodies generally, as Bichat's tissues did, but the whole material world. "Empedocles says that fire and earth and the related bodies are elementary bodies of which all things are composed; but this Anaxagoras denies. His elements are the homoeomerous things (having parts like each other and like the whole of which they are parts), viz. flesh, bone and the like." A principal characteristic of a Homoeomerous Part is that it is indefinitely divisible without changing its properties; it can be chopped up very finely to divide it, but is not otherwise changed in the process. The parts are like each other and like the whole Part, but not actually identical. Limbs, in contrast, obviously do not qualify; they cannot be chopped into littler limbs.

Aristotle starts his own explanation with the example of minerals: "By homoeomerous bodies I mean, for example, metallic substances (e.g. bronze, gold, silver, tin, iron, stone and similar materials and their by-products) ...;"' and then goes on to biological materials: "and animal and vegetable tissues (e.g. flesh, bone, sinew, ${ }^{4}$ skin, intestine, hair, fibre, veins) from which in turn the anhomoeomerous bodies - face, hand, foot and the like-are

* Dr John M. Forrester MA, BM, BCh, 120 Morningside Drive, Edinburgh EH10 5NS.

This paper owes much to the comments of the Editors and anonymous referees of Medical History. Comments on a draft of this paper by Professors K. J. Fielding, A. G. E. Pearse and the late D. Whitteridge FRS are gratefully acknowledged.

\footnotetext{
' Xavier Bichat, Anatomie générale appliquée à la physiologie et à la médecine, Paris, Brosson, Gabon et Cie., 1801, préface.

${ }^{2}$ Aristotle, De caelo, transl. J. L. Stocks, Oxford, Clarendon Press, 1922, 302a. Anaxagoras probably did not himself use the word Homoeomerous: see G. S. Kirk, G. E. Raven and M. Schofield, The presocratic philosophers, 2nd ed., Cambridge University Press, 1983, p. 366.

${ }^{3}$ Aristotle, Meteorologica, transl. H. D. P. Lee, London, Heinemann, 1952, Book IV, ch. x, 388a.

${ }^{4}$ The Greek word is $\nu \in \hat{v} \rho o \nu$ (neuron), which is translated as "sinew" in the works of Greek writers up to Galen's time. Galen himself discussed its meaning: see his On anatomical procedures, the later books, transl. W. L. H. Duckworth, Cambridge University Press, 1962, Book XIV.2.233-34, p. 185, and also his Elementary course on bones (see C. Singer, 'Galen's elementary course on bones', Proceedings of the Royal Society of Medicine, 1952, 45: 767-76), where he distinguishes "voluntary neura" linked to brain and spinal cord, i.e. nerves, from tendons and ligaments.
} 


\section{The homoeomerous parts and their replacement by Bichat's tissues}

composed".5 How can a chopped-up piece of vein still be a vein? He deals with this by saying that some Homoeomerous Parts have a specific shape as well-though presumably small pieces must lose it.

He lists elsewhere as Homoeomerous Parts flesh, bone, sinew, skin, intestine, hair, fibre, and blood vessels, and presently adds milk, urine, semen, blood, fish-spine, serum, lard, suet (one of these two is to him the form of fat in any one animal, lard being the softer), bone marrow, and bile. ${ }^{6}$ Later in the same work, nails, hoofs, claws, horns, beaks, and teeth are also mentioned. ${ }^{7}$ This is the widest range of biological Homoeomerous Parts offered by Aristotle. ${ }^{8}$

These Homoeomerous Parts were not developed by Aristotle in order to provide a descriptive nomenclature. They were one aspect of a comprehensive attempt at explanation of how things are, and also of how they have come to be so. Homoeomerous Parts can be brought into existence, and kept in existence, and exhibit qualities like hardness and softness, without a form or shape being imparted to them; ${ }^{9}$ yet they cannot exist in reality on their own, but only as part of a complete organism. Alone, they exist "in name only", and at death, as Fernel mentions many centuries later, they revert back to their constituent Four Elements. ${ }^{10}$

The solid Homoeomerous Parts provide the materials for Anhomoeomerous Parts of a body, which are conformations like arms and legs and organs, which do possess shape and also have specific functions. Thus bone is for Aristotle a Homoeomerous Part, but from it any individual bone can be created, when a shaping power operates upon the Homoeomerous Part. An individual bone has a shape and a function. It is an Anhomoeomerous Part. Other Homoeomerous Parts are fluids, and they can serve as "nourishment" for the solid ones; and some such as faeces and urine are mere residues.

What is the flesh which can be finely divided, yet each piece is still the same? It is apparently true red muscular tissue; to think it perfectly homogeneous seems strange, ${ }^{11}$ but no more so than his belief that the contraction came from the fibrous parts of muscle, including its sheath, and not from what we now recognize as the active part. Aristotle, unaware that the red part contracted, believed it to be connected with the sense of touch, and in fact to be the path conveying the stimuli of touch inward to the great common sense

\footnotetext{
${ }^{5}$ Aristotle, op. cit., note 3 above. He continues by referring to plants: "in plants, examples are wood, bark, leaf, root and the like", but each is an example of what? - of an anhomoeomerous organ, or of a Homoeomerous Part? In the context the answer is not evident. The translator holds that Aristotle is writing carelessly, and that wood and bark are homoeomerous, leaf and root anhomoeomerous. Aristotle remarks elsewhere (in De partibus animalium) that "plants ... present no great variety in their heterogeneous parts". Incidentally, the word "tissues" is the translator's insertion; Aristotle has no word signifying "tissues" and employs the neuter plural of an adjective such as "vegetable" to convey his meaning.

"Aristotle, De partibus animalium, trarss. W. Ogle, Oxford, Clarendon Press, 1911, Book II. 2, 647b, p. 22.

${ }^{7}$ Ibid., Book II. 9.

${ }^{x}$ In Historia amimalium (transl. D’Arcy W. Thompson, Oxford, Clarendon Press, 1910, Book I. 1. 486a), he mentions only flesh; in De caelo, op. cit., note 2 above, 302a, flesh and bone. It is hardly surprising that the fullest treatment is contained in the treatise entitled De partibus animalium.

${ }^{9}$ See Montgomery Furth, Substance, form and psyche: an Aristotelean metaphysics, Cambridge University Press, 1988, for further explanation of these concepts in a contemporary idiom.

10 Jean Fernel, Universa medicina, 6th ed., Hanover, heirs of Marnius, 1610, Lib. II, cap. iii. The first edition was published in 1567, and the editions are discussed in the bibliographical list of Sir Charles Sherrington's Endeavour of Jean Fernel, Cambridge University Press, 1946.

"Aristotle, op. cit., note 8 above, Book I. 1, 486a.
} 
organ, the heart. ${ }^{12}$ He held on theoretical grounds that each Homoeomerous Part must be responsible for some individual sensory function, while motor activity was the role of Anhomoeomerous (composite) Parts. ${ }^{13}$

The heart is unique in Aristotle's system: it is made out of one Homoeomerous Part only (i.e. "heart"), but this is specifically shaped so that it becomes the heart-an Anhomoeomerous Part or organ. It also has a specific role in embryogenesis; the formation of both Homoeomerous and Anhomoeomerous Parts proceeds simultaneously, and heart on Aristotle's observation was the first of both to emerge.

For Aristotle and a long sequence of successors, there was a difficult question: "How, we ask, is any plant formed out of the seed, or any animal formed out of the semen?" 14 The new animal resembled its parents, and especially in its Anhomoeomerous Parts. Is there a miniature set of these in the semen, and/or samples of the Homoeomerous Parts which are their initial substance? Aristotle argued that instead the semen contained the power or faculty to create both kinds of Part; it contained not actual Parts, but potential Parts, and the potential Parts seemed very real to him, since they are his explanation for the emergence of the actual Parts. ${ }^{15}$ The source material on which they work is the female contribution. This line of thought, incidentally, precluded the inclusion of semen itself among the Homoeomerous Parts; it was not an actual source material, and Aristotle termed it a "useful residue". ${ }^{16}$

No list of the biological homogeneous or Homoeomerous Parts claiming completeness comes from Aristotle, who presumably saw nothing fundamental in such a list. ${ }^{17}$

In the writings of Galen (approximately 129-200/216 AD) the same concept of Homoeomerous Parts is discussed several times in the course of various works which survived in Greek text, but his lists of them are not at all concordant, although for him, as tissues were for Bichat, they are to be discovered by dissection. ${ }^{18}$

His lists range from four ${ }^{19}$ or six, ${ }^{20}$ to ten or eleven. ${ }^{21}$ The number, whatever it is, ought to be determinate for any specific animal, since he writes at one point that the alterative

\footnotetext{
${ }^{12}$ Aristotle, op. cit., note 6 above. The matter of what contracts in a muscle is discussed in note 20 to Book III. 4 , on p. 197, and the matter of muscle as a sense organ is discussed in note 10 to Book II. 10, on pp. 173-4; it appears that Aristotle believed that muscle conveyed the stimulus inward to a deeper sense organ, the heart, which sensed everything.

${ }^{13}$ Ibid., Book II, 647a: "For it is in homogeneous parts alone that sensation can occur ... Sensation is then confined to the simple or homogeneous parts."

${ }^{14}$ Aristotle, De generatione animalium, transl. A. Platt, Oxford, Clarendon Press, 1910, 733b.

${ }^{15}$ Aristotle, De generatione animalium, transl. A. L. Peck, London, Heinemann, 1943, 726b: The "semen of the hand... really is hand in an undifferentiated way: what each part is in actuality, the semen is potentially."

${ }^{16} \mathrm{He}$ had earlier listed it as a Homoeomerous Part; see note 6 above.

${ }^{17}$ Nor, between his time and Galen's, does one come from Anonymus Londinensis, who writes briefly that there are simple and compound parts of the body; simple ones are homoeomerous and so divide into like parts, and brain, sinew (see note 4 above), artery and vein are the examples he gives; see W. H. S. Jones, The medical writings of Anonymus Londinensis, Cambridge University Press, 1947, pp. 82-3. His compound parts include liver, so that a modern reader emerges a little puzzled at his choices, expecting that liver would present more homogeneity than an artery.

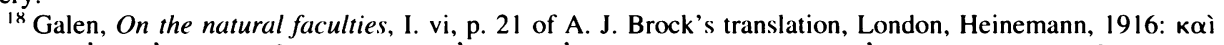

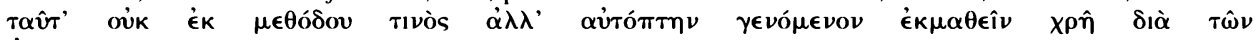
$\alpha \dot{\alpha} \alpha \tau \operatorname{To} \hat{\omega} \nu:$ "personal observation of dissections".

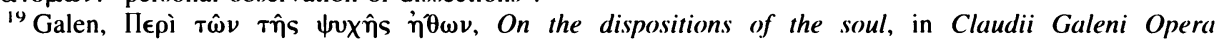
Omnia, 20 vols., ed. C. G. Kühn, Leipzig, C. Cnobloch, 1821 (hereafter Kühn), vol. 4, p. 773. Besides bronze, iron, and gold, flesh, nerve, cartilage and fat are listed, and "all what Plato called Protogona and Aristotle Homoeomerous." It would be of interest to discover the source of the remark about Plato, which Galen repeats
} 


\section{The homoeomerous parts and their replacement by Bichat's tissues}

faculties (which each create one Homoeomerous Part) in each animal are of the same number as the Parts. ${ }^{22}$ For him, in the first stage of embryogenesis the Homoeomerous Parts are created through the activity of these faculties.

It had always been known that Galen had devoted a whole treatise to the topic of Homoeomerous Parts, but it had to be recovered from the Arabic, the original Greek not having survived. ${ }^{23}$ In it, the definition of the word homoeomerous seems elastic; it does not require real likeness of the Parts to other parts of themselves-only a certain resemblance. Yet the nature of their substance must be in its entirety one and the same. Much as for Aristotle, brass, ice, gold and lead pass the test; unrefined ores do not.

Then Galen sets out specifically to enumerate the Homoeomerous Parts of the human body. Epidermis manifestly qualifies. The subcutaneous fascia is separable and different. Galen touches on a feature that recurred again with Bichat's tissues: a Homoeomerous Part ought to have its own specific action (which for Galen has to be an active voluntary or involuntary movement) or function (which for him need not be a movement, but is not necessarily a sensory function). Epidermis has a function: to cover and provide a surface for the body. Bones lack the function of sensitivity, as a rule; sensitivity only exists through the nerves, which conduct it outwards to the parts of the body that have it. To think of sensitivity as an outgoing rather than an incoming faculty was not alien to Galen, who even thought of sight as a faculty emerging from the eyes. ${ }^{24}$

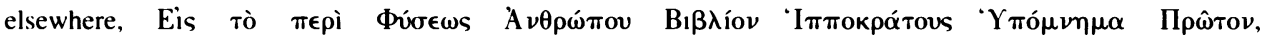
Hippocratis de natura hominis liber primus et Galeni in eum commentarius, in Corpus Medicorum Graecorum V.9.1, J. Mewaldt, G. Helmreich, J. Westenberger (eds), (hereafter CMG) Leipzig and Berlin, Teubner, 1914, p. 6; also in Kühn, vol. 15, p. 8, but the word "Protogona" does not occur anywhere in Plato's surviving writings, as I have verified through the computer database Ibycus. The nearest word is "protogenes" in Politicus $288 \mathrm{E}$ and $289 \mathrm{~A}$, applied inter alia to bronze, iron and other basic material.

${ }_{20}$ Galen, op. cit., note 18 above. The list of Homoeomers is in Book I. vi. 12, p. 21, and comprises: bone, cartilage, ligament, sinew/nerve, membranes, veins (blood vessels).

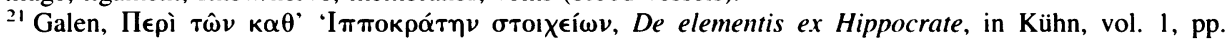
413-571. The list of Homoeomers is on pp. 465-6 and comprises: bone, cartilage, ligament, nail, hair, lard,

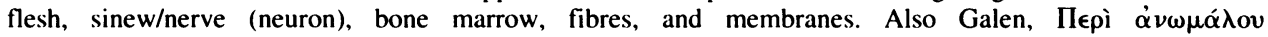

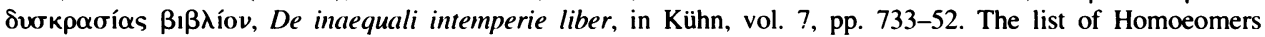
on p. 735 comprises: bone, cartilage, ligament, sinew/nerve, arteries, veins, membranes, flesh, tendon, nail, skin, lard-but arteries and veins are then withdrawn again, as being composed of fibres and membranes.

22 Galen, op. cit., note 18 above, I. vi, p. 23, but using the expression "elemental parts".

${ }_{2.3}$ Galen, Ueber die Verschiedenheit der homoiomeren Körperteile, or in Latin, De partium homoeomerium differentia, CMG, Suppl. Orient., ed. Gotthard Strohmaier, Berlin, Akademie-Verlag, 1970.

${ }_{24}$ Plato, Timaeus, in Dialogues of Plato, transl. B. Jowett, Oxford, Clarendon Press, 1953, vol. 3, pp. 631-780. Ch. 45 , p. 731 , describes a "stream of fire" flowing (out) through the eyes; "when the light of day surrounds the stream of vision, they coalesce, and one body is formed ... wherever the light that falls from within meets with an external object." Plato, maintaining that a "stream of vision" emerges from the eye, rather than light entering it, has to account for two obvious matters of experience: vision fails in darkness, and it fails when the eyelids close. The former he explains by supposing a collaboration between the emerging stream and the external light; the latter he explains by blockage of the emerging stream. We are still unconsciously using a similar model when we say: "His gaze fell upon his friend."

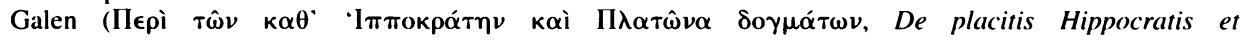
Platonis, in Kühn, vol. 5, pp. 181-805; and in CMG, ed. P. De Lacy, Berlin, Akademie Verlag, 1980, vol. 4, 1.2, pp. 454-5) followed Plato's line, which was not followed by Aristotle (see his De sensu, transl. J. I. Beare, Oxford, Clarendon Press, 1908, 438a: "It is . . . an irrational notion that the eye should see in virtue of something issuing from it.") Galen wrote in ch. 5 of Book VII (Kühn, p. 619): "the ambient air seems to undergo a change in response to the emergence of the Pneuma (from the eye), similar to its change in response to the sun's light ..." - -and visual perception ensues when the emergent Pneuma encounters an object. The Pneuma is a mysterious spiritual entity, comparable to Plato's "stream of vision". 
An eighteen-item list of homoeomers is now presented: "Tooth, bone, cartilage, nerve, ligament, tendon, brain, spinal cord, subcutaneous fascia, ${ }^{25}$ simple $^{26}$ flesh, fibrous tissue $\mathrm{e}^{27}$ which is in muscle, fat glands, and in the eye the vitreous humour, the ice-like humour [i.e. lens], the horny layer [cornea], the grape-like layer [uvea], and the two hollow nerves; and you may add the thin [aqueous] humour which surrounds the ice-like one, which may or may not be a part of the body, as are blood and Pneuma." Epidermis seems to have slipped out. The pia and dura mater surrounding the brain are presently added, and there is prolonged discussion of matters like the composition of vessels and of the gut, which have several coats, but whether these coats consist themselves of Homoeomerous Parts or not does not clearly emerge. Stating that he has now mentioned all the Homoeomerous Parts (but not how many there are), he proceeds to list the Large Organs, and the Layered Parts (arteries, veins, nerves, tendons, muscles). In conclusion, he writes, bone, cartilage, membranes, glands, flesh belong to the Homoeomerous Parts, and are the real elements ${ }^{28}$ making up the human body.

The translator thinks that Galen has listed "about 45" Homoeomerous Parts here. From the discordant crosscurrents of thought in the work it is impossible to say, and the translator does not risk naming them. Galen's discussion is discursive and confusing, but he made an overt attempt at enumerating the Homoeomerous Parts of the human body, which Aristotle did not do. ${ }^{29}$

\section{THE HOMOEOMEROUS PARTS AND THE FOUR ELEMENTS}

Although Galen, like Anaxagoras before him, referred to the Parts occasionally as "elements", 30 he considered, as Aristotle did, that they were composed out of the Four Elements. ${ }^{31}$ Aristotle conceived flesh as constituted from fire and earth, like wood and "other similar bodies", 32 but stated no proportions. Elsewhere, he maintained that horn, nail, bone, sinew, wood, hair, leaves, and bark are constituted from earth and water, earth preponderating; blood and semen consist of earth, water, and air. ${ }^{33}$

There are no more precise formulae in terms of the four elements, nor attempts to provide them by, for instance, weighing techniques. "Composition was inferred from the resemblance of the qualities, not from the separate exhibition of the ingredients. The supposed analysis was, in short, a decomposition of the body into adjectives, not into

\footnotetext{
25 "Hülle" in the German translation.

26 "bare" in German.

27 "Fasern".

28 "wahrnehmbaren Elemente".
}

${ }^{29}$ In this treatise he does not make a distinction in terms of their developmental origin between "spermatic, or fleshy" and "sanguineous" homoeomerous parts; L. J. Rather (The genesis of cancer, Baltimore, Johns Hopkins University Press, 1978, p. 50) has traced this distinction from Galen on to the Medicina of Bartholomew Pardoux (1641).

${ }^{30}$ See note 28 above and e.g. Galen's On the natural faculties (note 18 above) I. vi: $\alpha$ ı́ $\theta \eta \tau \grave{\alpha} \sigma \tau o ı X \epsilon \hat{\alpha}$ : "sensible elements". See also, C. J. Larrain, Galens Kommentar zu Platons Timaios, Stuttgart, Teubner, 1992, frag. 3, pp. 41-9.

${ }^{31}$ Details of the divergent views of Aristotle's predecessors are succinctly presented in Thomas S. Hall's Ideas of life and matter: studies in the history of general physiology $600 \mathrm{BC}-1900 \mathrm{AD}$, University of Chicago Press, 1969 , vol. 1 , p. 48

${ }^{32}$ Aristotle, op. cit., note 2 above, 302a 16, Book 3.3 .

${ }^{33}$ Aristotle, op. cit., note 3 above, Book IV, ch. x, 388a. 


\section{The homoeomerous parts and their replacement by Bichat's tissues}

substances." ${ }^{34}$ Indeed, Aristotle seemed to feel, as Furth argues, ${ }^{35}$ that to specify proportions shows a lack of appreciation of the difference between structure and mere mixture. So the proportions of the four required to make up any particular Homoeomerous Part did not require specification.

There is however a set of proportions in another of Galen's works surviving in the Arabic, in which he remarks that blood is four parts fire, three earth, four air and six water, without giving reasons. ${ }^{36}$ The position of blood among the Homoeomerous Parts was always, as in Galen's treatise upon them, precarious. Aristotle had included it, along with less likely candidates such as urine and milk. Galen is here equivocal. Fernel excluded it. ${ }^{37}$ Even in the twentieth century, its position among the tissues is similarly ambiguous, pace Rather, ${ }^{38}$ it can still be presented among the Tissues of the Body. ${ }^{39}$

How did Galen arrive at these proportions for blood as he spoke or dictated $?^{40}$ It is impossible to tell from the context. Indeed, as Fernel remarked, ${ }^{41}$ specifying such proportions is not feasible.

\section{LATER HISTORY OF THE HOMOEOMEROUS PARTS}

Rechristened usually in Latin as the Similar or Consimilar Parts, they were still receiving earnest comment in the sixteenth century. Fernel provided a broadly Aristotelian discussion of the Similar and Dissimilar Parts, then concluded by providing a short list of "elements" (bone, cartilage, ligament, tendon, membrane, nerve, artery, vein, "flesh," skin) indivisible into different substances except at death. ${ }^{42}$ Fallopius thought them worth a special treatise (1575). ${ }^{43}$ He too recapitulated Aristotle, and expounded his doctrines with

\footnotetext{
${ }^{34}$ W. Whewell, History of the inductive sciences, 3rd ed., London, J. W. Parker, 1857, vol. 3, p. 95. But Jean Fernel three centuries earlier strongly protested against this interpretation: see his Universa medicina, op. cit., note 10 above, Physiologia Lib. II, cap. vi.

${ }^{35}$ Furth, op. cit., note 9 above, p. 91 . Furth is probably relying on passages like De generatione et corruptione 33.3 b 13 , II. 6 .

${ }^{36}$ Galen, Ueber die medizinischen Namen, ed. M. Meyerhof and J. Schacht, Abhandlungen d. Preuss. Akad. d. Wiss., Phil-Hist KI., 1931, no. 3, p. 14, 29 f. (Arab.)=p. 28, 9-12 (German). The German translation runs: "Ein Beispiel dafür [of the inadequacy of compositions specifying only one or two humours] ist, dass es sich als Wahrheit erweist, dass im Blute vier Teile Feuer, drei Teile Erde, vier Teile Luft und sechs Teile Wasser enthalten sind und dass seine Natur nach diesen Verhältnissen aus diesen Teilen zusammengesetzt ist; das ist die wahre Wissenschaft von der Natur des Dinges." As Strohmaier remarks (op. cit., note 23 above, p. 91), the reader is astounded to be told this composition for blood is established as fact!

${ }^{37}$ See Hall, op. cit., note 31 above, p. 191: Fernel "went to great pains to distinguish 'true' simple parts (bone, cartilage, ligament, membrane, tendon, nerve, artery, vein, flesh, and skin) from others that were not, for him, parts in the strict sense (blood, milk, the humors, spirits, bone marrow, hair, nails, fat, etc.)."

${ }^{38}$ Rather, op. cit., note 29 above, p. 48.

${ }^{39}$ W. E. LeGros Clark, The tissues of the body, 2nd ed., Oxford, Clarendon Press, 1945, p. 209.

${ }^{40}$ Galen certainly employed shorthand writers, which might then, as now, help to explain hastiness and prolixity of thought. An Oxyrhynchus papyrus record dated AD 155 shows the Greek shorthand system "in full working order", and a slave being sent on a two-year course in it for a specified fee. See H. J. M. Milne, Greek shorthand manuals. Syllabary and commentary, London, Egypt Exploration Society, Bernard Quaritch etc., 1934, p. 2.

${ }^{4}$ Op. cit., note 10 above, Lib, III, cap. v: "Quisquis compositi corporis temperamentum ex insertis elementorum portionibus aestimare volet, cognitionem multis obstructam difficultatibus et rebus obscuris petitam suscipiet. Occulta enim sunt et penitus abditae simplicium vires."

+2 Ibid., Lib. II, caps. i-iv.

${ }^{4.3}$ Gabriel Fallopius, Lectiones de partibus similaribus humani corporis, gathered by A. Coiter, Nuremberg, Theodoric Gerlach, 1575.
} 


\section{John M. Forrester}

evident respect. He presented a list of twenty Parts, ${ }^{44}$ and quoted a different list of nine from Avicenna (980-1037 AD) $)^{45}$ and yet another of sixteen from Averroës (1126-1198 AD).$^{46}$ For Galen, whose various lists were not concordant with each other, he indicated a particular scorn. ${ }^{47} \mathrm{He}$ discussed the origin and function of each Part so far as he could. For instance, "flesh" (which to him seems to be roughly parenchyma of various organs, and not particularly voluntary muscle) has the following functions: to convey the sense of touch; to fill up cavities; to fill capsules; to link arteries and veins; to support nerves; and other less clear-cut functions.

Laurentius made it an early and principal aim of his book on the anatomy of the human body (1600) to go through the Homoeomerous or Similar Parts one by one; he used four sections of his very substantial work ${ }^{48}$ to explain the whole body as an assembly of these Parts, and the remaining seven sections to resolve the whole again into Dissimilar Parts-organs, limbs, etc. How many Similar Parts?-he papered over the cracks in Galen's accounts, and finished with a list of ten. ${ }^{49}$

The young William Harvey at the start of his notes for his anatomical lectures (begun in 1616) paid conventional regard to the traditional set of Similar Parts, ${ }^{50}$ and specified some 39 of them. He outlined the headings ${ }^{51}$ that might be used to describe a Similar Part, but did not apply them to any single Part. He also repeated the Aristotelian view that sensibility resides only in Similar Parts. But the mature Harvey was critical of the ancient pre-Aristotelian view ${ }^{52}$ that in embryogenesis miniature Similar Parts and even Dissimilar Parts pre-exist in the seed, and then the more complex parts are created out of them, so that "bones from tiny and minute bones spring", and affirmed that he could not find during embryogenesis, or make out by rational argument, a stage where the Similar Parts exist ready to be mixed and united into organs, limbs and the whole animal. ${ }^{53}$ Similar Parts thus

\footnotetext{
${ }^{44}$ Blood, bile, milk, ichors, fat, marrow, flesh, viscera, nerves, veins, arteries, skin, membranes, bladder, bone, cartilage, hair, nails, horn, feathers.

${ }^{45}$ Bone, cartilage, nerve, chordae (tendon, perhaps), ligament, arteries, veins, membranes, flesh.

${ }^{46}$ Bone, muscle, chordae, nerve, ligament, flesh, axungia (fat, classically, "axle-grease"; Castelli's Lexicon graeco-latinum of 1644 gives "old pig fat" as the then current meaning), skin, hair, nails, phlegm, the four humours, spirit.

${ }^{47}$ Fallopius, op. cit., note 43 above, Sect. 4: "Haec est dementia huius viri, qui mihi non placet."

${ }^{48}$ Andreas Laurentius, Historia anatomica humani corporis et singularum eius partium . . . Frankfurt, Becker, 1600.

${ }^{49}$ Ibid., Quaestio V in Controversiae Libri Primi, p. 27: "Itaque apud Galenum locis citatis, hae erunt similaria corpora, os, cartilago, ligamentum, membrana, fibrae, nervi, arteriae, venae, caro, cutis, adeps, medulla, ungues, pili. Nos vero quia medullam, pilos, adipem, ungues a partis definitione exclusimus, nec eas etiam similares appellandas censimus." Galen, he says, gave as Similiar Bodies bone, cartilage, ligament, membrane, fibre, nerve, artery, vein, flesh, skin, fat, marrow, nails, hairs. Laurentius excludes marrow, hair, nails and fat. He is keen to defend Galen against the reproach of inconsistency.

${ }^{50}$ William Harvey, The anatomical lectures of William Harvey, ed. and transl. Gweneth Whitteridge, Edinburgh, E. \& S. Livingstone, 1964. Folio 2 (pp. 9 and 11 of the translation) mentions the following: (a) liquids: blood, sperm, milk, ocular humours (2), rheum, bile, mucus, tears, ichor, serum; (b) solids: (i) soft: flesh of muscle. of gums etc., of parenchyma, and of glands, marrow, fat, lard, brain, lens of eye; (ii) firmer: fibre, membrane, vein, artery, skin, nerve, tendon, ligament; (iii) hard: bone, teeth, carapace, hair, cartilage, nail, claw, horn, quill, beak, feathers, scales. Harvey does not spell the Greek word "homoeomere" correctly, although his manuscript flows freely from Latin into English and back again.

51 Ibid., pp. 22-3.

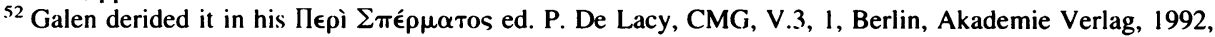
Book II, cap, iii, p. 164.

${ }^{53}$ William Harvey, Disputations touching the generation of animals, transl. Gweneth Whitteridge, Oxford, Blackwell Scientific Publications, 1981, ch. 72.
} 


\section{The homoeomerous parts and their replacement by Bichat's tissues}

could not form the channel of continuity between parent and offspring. Harvey, incidentally, doubted the Four Elements too.

By the early eighteenth century, Boerhaave no longer used the Similar or Homoeomerous Parts even for descriptive convenience; neither his anatomy nor his physiology had need of them, and a mere ghost of them survived in his pathology. Haller (1708-1777) allowed them no role in his anatomy and physiology, ${ }^{55}$ which depended much more upon a micro-system of ultimately invisible fibres as their basic constituents. ${ }^{56}$ An opportunity for a new set of body constituents was opening.

Bichat's set is justly celebrated, and has often been discussed. Each of his tissues possessed a distinct function and indeed a life of its own. ${ }^{57}$ As Lesch points out, ${ }^{58}$ Bichat's set of tissues was much more than a group of anatomical descriptive terms; it was a "taxonomy of vital properties", and consequently provided a basis for a new pathological anatomy and a new therapeutics.

Foucault discerned a range of changes in modes of thought occurring at the end of the eighteenth century, described by him as new "languages". ${ }^{59}$ Hence it is not surprising that a few years later, in his The birth of the clinic, ${ }^{60}$ he referred to the language of tissues as one in which part of the medical knowledge of a patient could be expressed. The name of this new language had emerged rather earlier. The word "tissu" with a biological sense appeared first in French. 61 The corresponding Latin word "tela" (a web) was used previously. ${ }^{62}$ Rather sees in the famous title of Vesalius's still earlier work De humani

${ }^{54}$ Institutiones medicae. De morbis (pathologia), in his Opera omnia, 3rd ed., Venice, Laurentius Basilius, 1757, p. 96, sect. 700: "morbus partis solidae simplicissimae, similaris dictus, proprie . . obtinet in fibra ultima" -a pathology of fibres and membranes, not of Parts.

${ }^{55}$ Rather, op. cit., note 29 above, p. 55.

56 Hall, op. cit., note 31 above, in vol. 1, ch. 27.

${ }^{57}$ Ibid., vol. 2, on pp. 123 seq. these functions are discussed.

$5 \times$ John E. Lesch, Science and medicine in France: the emergence of experimental physiology, 1790-1855, Cambridge, Mass., Harvard University Press, 1984.

${ }^{59}$ Michel Foucault, The order of things: an archaeology of the human sciences (French title: Les mots et les (hoses), London, Tavistock publications, 1970, p. 62: "It is no longer the task of knowledge to dig out the ancient Word |sic| from the unknown places where it may be hidden; its job now is to fabricate a language, and to fabricate it well-so that, as an instrument of analysis and combination, it will really be the language of calculation."

${ }^{(6)}$ Michel Foucault, The birth of the clinic (French title: Naissance de la clinique), transl. A. M. Sheridan, London, Tavistock Publications, 1973, p. xviii.

${ }^{61}$ The first instance I have noted is in J.-B. de Senac, Traité de la structure du coeur et son action, et de ses maladies, Paris, Vincent, 1749, p. 448. In discussing intracardiac "polyps", he writes that there was no fault in the heart's tissu, and elsewhere in the same work uses the word similarly. Originally, of course, it meant "a woven thing"; indeed, it was being used as the past participle of the verb "tisser" (to weave) in a passage published in 1767 referring to the weaving of a biological membrane: Théophile de Bordeu, Recherches sur le tissu muqueux ou organe cellulaire et sur quelques maladies de la poitrine, Paris, Didot le jeune, 1767 (date of the work being done is given by the editor in the preface as 1743-5), section 52: the verb "tisser" is used to indicate the weaving of a membrane: "ces portions... se sont aussi collées et ont tissu une sorte de membrane". The same grammatical relation is evident in 1823: "Leurs particules [of organs] sont entrelacées, entrecroisées, tissues, aussi nomme-t-on leur arrangement texture." (P. A. Béclard, Elémens d'anatomie générale, Paris, Béchet jeune, 1823, p. 3.)

"2 Fallopius, op. cit., note 43 above; section 12 refers to tela as a new-fashioned term. Another Latin word "textura" or "contextura" was also in use, and at first denoted a characteristic of biological material, rather than a component of it; e.g. Marcello Malpighi, Opera omnia botanico-medico-anatomica, Leyden, P. Vander, 1687, p. 299: de Liene (capsule of spleen) "horum arcta et intima continuatio cum propria lienis investiente membrana, et cum elongatis inde fibris, istis primas conferre videntur, cum facile sit naturae levi ipsarum textura membranosos in liene parietes efformare" (easy for nature to create, from a delicate weave of fibres, membranous partitions in the spleen). Similarly in his Anatome plantarum (in Opera omnia, London, Sawbridge, 1686), p. 6: "Simplicior igitur contextura in tenellis caulibus..."-there is a simpler texture in the fine stalks. And Nehemiah Grew, Anatomie 
corporis fabrica a reference to woven fabrics, but, as is maintained by other authors he cites, "fabrica" is originally the work of someone using hard materials, so that "structure" is the appropriate translation of "fabrica". 63 Only in the eighteenth century did "fabric" become a name for a fabric woven of textile.

The first "word" of the tissue language to come into use was what is now known as areolar connective tissue, the insubstantial mesh found between many organs of the body, which turns out to be continuous with connective tissue existing round and through organs. This was hardly a new discovery; Galen mentions these "fibre branches finer than spiders' webs", ${ }^{64}$ but their recognition as part of an important tissue of the body took place only about the start of the eighteenth century.

The usual name at first was tela cellulosa, the "cells" being the spaces of the network or web, and only very remotely related to the cells of later biology. Haller knew that the tissue's importance had been recently recognized in his time, and that the name was a new one, but did not credit any individual. ${ }^{65}$ The original Encyclopédie was explaining in 1751 that tissu cellulaire was an important structural component of the human body. ${ }^{66}$

\section{EVIDENCE LEADING TO THE RECOGNITION OF AREOLAR CONNECTIVE TISSUE}

Anatomy by now had developed serviceable techniques well beyond mere cutting or tearing. The one that most illuminated the role of areolar connective tissue was inflation

of plantes, original publication 1682; reprinted in New York and London by Johnson Reprint Corporation, 1965, Book 1, ch. 1, sect. 18, p. 4: parenchyma is one component of a bean, "The surface hereof" is somewhat dense, but inwardly, 'tis of a laxer Contexture". Similarly in Book 2, ch. 3, sect. 7, p. 64, Parenchyma of Roots "in many Roots is of one Uniform Contexture." And similarly in ch. 4, sect. 1, p. 119.

${ }^{6.3}$ Rather, op. cit., note 29 above, p. 51.

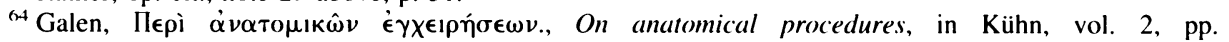
349-50. Charles Singer, in his Galen on anatomical procedures, London, Oxford University Press, 1956, p. 63, omits these, writing: "Here follow two displaced pages of a trivial discussion of terms, a translation of which would be purposeless." In fact the "trivial discussion" does not appear displaced at all, but is merely repetitious in Galen's usual fashion, and stresses that skin and subcutaneous fascia are distinct, though both usually come away together when flaying is done. Galen insists that the two must be carefully separated while being removed. In particular, he

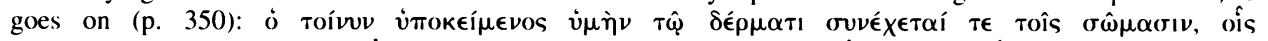

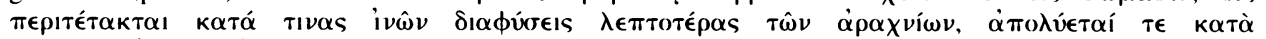

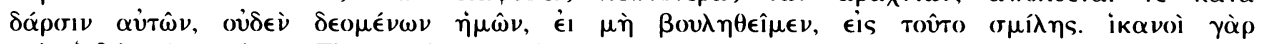

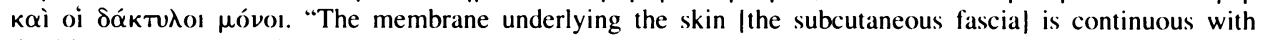
the [deeper] structures it surrounds, through fibre branches finer than spiders' webs, and is freed from them [the structure, presumably] on flaying, without our requiring a scalpel for the purpose, unless we want one; fingers alone are enough. But the membrane cannot be separated from the skin by fingers alone; a scalpel is needed, because the two have grown together."

${ }_{65}$ Albert von Haller, Elementa physiologiae corporis humani, Naples, Vincent Ursino, 1776. He mentions as synonyms: cellulosus textus, tela cellulosa, membrana cellulosa, cellulositas. Other synonyms were: corps cellulaire, organe cellulaire, substance cellulaire, tissu muqueux, organe spongieux (Bordeu); tissu cellulaire, tela cellularis (Encyclopédie); membrana cellulosa, cellulosus textus (Haller); contextus fibrosus (quoted by Haller); corps cribreux, substance spongieuse (Dumas), textus filamentosus (Mayer).

${ }^{n}$ Encyclopédie, ou dictionnaire raisonné des sciences, des arts et des métiers, par une société de gens de lettres, mis en ordre et publié par M. Diderot ... et quant à la partie mathématique, par M. D’Alembert, Paris, Briasson (and others), 1751, vol. 2, p. 807: “cellulaire en anatomie se dit d'un tissu composé de plusieurs loges plus ou moins distinctes, qui paroît séparer toutes les parties du corps humain jusque dans leurs plus petits éléments... Le tissu cellulaire est composé de fibres et de lames toutes solides sans cavité ... arrosé par un vapeur aqueuse, gelatineuse et graisseuse, qui s'exhale des artères, et qui est reprise par les veines... Les extrémités des artérioles y déposent de la graisse, qui est repompée par les veines... On reconnoîtra l’importance de ce tissu, si l'on fait attention que c'est de lui que dépend la fermeté et la solidité naturelle de toutes les artères, des nerfs, des fibres musculaires..." 


\section{The homoeomerous parts and their replacement by Bichat's tissues}

with air or liquids. Inflation with air showed the continuity of the tissue, and displayed the "cells" clearly, ${ }^{67}$ and how vessels and nerves traversed it. ${ }^{68}$ Similarly, molten wax injections intended to distend the vessels of the blood circulation ${ }^{69}$ might leak out into the connective tissue, displaying it instead. ${ }^{70}$ And injection of air under the skins of horses or cattle might even be done by their owners, to enhance their size and value! ${ }^{71}$ In disease, oedema fluid clearly lodged in the tissue, and could move about in it. It was also noticed ${ }^{72}$ that a barrier exists between the left and right sides in the layer of the tissue below the skin at the midline.

\section{AREOLAR TISSUE EXTENDED}

This loose mesh between organs was seen early as the place where fat lodges, and then as just one part of a much more widely distributed component of the body. Haller ${ }^{73}$ discerned how with some transformation it formed ligaments and tendons and membranes, how it penetrated into bone, into arterial sheaths, into the coats of the intestine, into muscle, into viscera as their fibrous skeleton (displayed by soaking them in water and removing the more fugitive components ${ }^{74}$ ), into cartilage, even into the vitreous humour of the eye; but little or not at all into the nervous system. It was seen later as a structureless gel, given form only by distension or post-mortem coagulation. ${ }^{75}$ A remarkable physiological role for it was

\footnotetext{
${ }^{67}$ See Ruysch`s reply in p. 9 seq. of Johannes Gaub, Epistola problematica prima ad . . F. Ruyschium, Amsterdam, Wolters, 1696, in Frederik Ruysch, Opera omnia anatomico-medico-chirurgica, 2 vols, Amsterdam, Jansson-Waesberge, 1721. Ruysch found fat in the scrotum, and its "membrana nil minus quam cellulosa videatur"; and inflation with air and drying produced layers and cellulae.

${ }^{68}$ Alexander Monro (primus), "An essay on the method of preparing and preserving the parts of animal bodies for anatomical use', in Medical essays and observations published by a Society in Edinburgh, 1746, 2: 1-9. "The membrana cellularis cannot be kept inflated, unless it has little or no fat." Also see David Christoph Schobinger (of St Gall), De telae cellulosae in fabrica corporis humani dignitate, Göttingen, Abram Vandenhoeck, 1748.

(") F. J. Cole, 'The history of anatomical injections', in C. J. Singer (ed.), Studies in the history and method of science, Oxford, Clarendon Press, 1917, vol. 2, pp. 285-343. Inflation with air is mentioned long before by Galen, referring to inflation of the subarachnoid space: see his On anatomical procedures, Kühn, Book IX, vol. 2 , p. 717.

${ }^{70)}$ Hermann Boerhaave, in Opusculum anatomicum de fabrico glandularum in corpore humano, continens binas epistolas, quarum prior est Hermanni Boerhave ad F Ruyschium, Altera F Ruyschii ad H. Boerhaave, Leiden, P. Vander, 1722, p. 35: "repletio fit panniculi adiposi, membranae cellulosae (my italics), corporis spongiosi penis, et similium." And Alexander Monro (primus), "An essay on the art of injecting the vessels of animals", in Medical essays and observations, published by a Society in Edinburgh, 1747, 3rd ed., vol. 1, pp. 79-92, on p. 88: "In all the parts where there is a remarkable tunica cellulosa, it never misses to be full of the water, which is apt to spoil any parts designed to be preserved either wet or dry."

${ }^{71}$ Schobinger, op. cit., note 68 above, p. 8.

72 Théophile de Bordeu, Recherches sur le tissu muqueux ou organe cellulaire et sur quelques maladies de la poitrine, Paris, Didot le jeune, 1767 (date of the work being done is given by the editor in the preface as 1743-5), sect. 71.

${ }^{7.3}$ Albert von Haller, Elementa physiologiae corporis humani, Naples, Vincent Ursino, 1776, (Introduction is dated 1757, at Berne) vol. 1, book 1, sect. 3, p. 13: "Nova hic propono... Fere omnes nempe corporis humani solidas partes meram cellulosam telam, strictius congestam, et arctius intricatam esse experimento cognovi. Certe membranas absque exceptione omnes, vasaque, quae membranae cavae sint, deinde viscerum parenchymata, ligamenta, forte et tendines, et cartilagines, et ossium partem magnam cellulosam telam aut esse, aut aliquando fuisse, per experimenta reperio."

${ }^{74}$ Schobinger, op. cit., note 68 above, p. 42, credits Highmore with this technique.

${ }_{75} \mathrm{~J}$. Henle in his Traité d'anatomie générale ou histoire des tissus, transl. A.-J.-L. Jourdan, Paris, J.-B. Baillière, 1843, pp. 416 seq., attributes this view to Bordeu, C.-F. Wolff, Blumenbach, Doellinger, Meckel and Rudolphi. It is in no way a surprising view; they could not see the fibres of connective tissue which the microscope reveals to us; and they identified undifferentiated embryonic tissue, which does not contain fibres, with mature areolar connective tissue.
} 


\section{John M. Forrester}

discerned by Richerand: in excess, by being wrapped round the nerve endings, it weakened the sensitivity of its owner. ${ }^{76}$ Thus excitable women are notably thin; and their paroxysms can be moderated by tightly bandaging body and limbs, so that their nerve endings are insulated.

The pervasive character of connective tissue was a genuine insight: collagen, the particular protein of connective tissue (of which areolar tissue forms one part), in fact constitutes one third of all the protein in the mammalian body, and is the most plentiful of all the proteins there. The crude beginnings of chemical analysis of areolar tissue appeared only a little later. ${ }^{77}$

Haller's pupil Schobinger wrote a monograph on tela cellulosa ${ }^{78} \mathrm{He}$ described how it formed tough membranes as well, and maintained that it offered a path through the whole body, one cell opening into another. He and his master saw a further role for it: not just as a sort of fibrous skeleton for the whole body, but also as the precursor material from which God made the whole body. Haller maintained that its original formation and its subsequent transformations could be observed in the developing hen's egg. ${ }^{79}$ Blumenbach, profoundly impressed by tela cellulosa ("among the principal and most memorable constituents of our body"), thought that bone-not its most obvious descendant - was the product when "bone juice" impregnated it. ${ }^{80}$ This sort of explanation was still on offer in the middle of the nineteenth century. ${ }^{81}$

\section{TECHNIQUES FOR IDENTIFYING TISSUES}

Today, its seems at first sight absurd that Bichat's primary tool should not be the microscope. Microscopes certainly existed, and had served biology since Leeuwenhoek and Malpighi. But Bichat preferred not to use one, because at that time the compound microscope had not reached a satisfactory performance, and microscopists' accounts conflicted with each other. ${ }^{82}$ Instead, he used the following techniques to separate one tissue from another:

${ }^{76}$ Anthelme Richerand, Nouveaux elémens de physiologie, 2nd ed., Paris, Crapart, Caille et Ravier, 1802, p. Ixvii.

${ }^{77}$ S. Th. Soemmerring, De corporis humani fabrica, Frankfurt-am-Main, Varrentrapp \& Wenner, 1794-1801. (The German original is: S. Th. Sömmering, Vom Baue des menschlichen Körper, Frankfurt-am-Main, Varrentrapp \& Wenner, 1791-96.), vol. 3, sect. 1 seq. The chemical analysis given is crude.

${ }^{78}$ Schobinger, op. cit., note 68 above.

${ }^{79}$ Haller, op. cit., note 73 above, vol. 9, Book 29, sect. 7: "Musculos enim ubi gelatina fuit, invenies, et vasa grandia, et aliquem in suam cellulosam telam effusum adipem."

${ }^{80}$ J. F. Blumenbach, Institutiones physiologicae, Göttingen, Dieterich, 1787, p. 32, sect. 43; he thinks all tela cellulosa possesses a vital force, and calls it "vis cellulosae". No discussion nor reference is given for this notion. For instance, it can contract, and squeeze out its contained fluid, he believed.

${ }^{81}$ G. H. Lewes, Comte's philosophy of the sciences, London, H. G. Bohn, 1853, p. 187. What is added to cellular tissue, he wrote, in order to make muscle, is fibrine (of known elemental composition), and to make nervous tissue, neurine (of similarly known composition).

${ }^{82}$ Xavier Bichat, Traité des membranes en général et de diverses membranes en particulier, nouvelle édition, Paris, veuve Richard et C. Méquignon l'aîné, 1802 (an xi), pp. 29-30: "La tenuité de ces prolongemens en dérobe la structure, même à nos instrumens microscopiques, espèce d'agens dont la physiologie et l'anatomie ne me paroissent pas d'ailleurs avoir jamais retiré un grand secours, parce que quand on regarde dans l'obscurité, chacun voit à sa manière, et suivant qu'il est affecté. C'est donc l'observation des propriétés vitales qui doit sur-tout nous guider ...". A similar remark is in his Anatomie générale (note 1 above), vol. 1, p. 581: "hypothèses anatomiques, pour lesquelles on a abusé du microscope". 


\section{The homoeomerous parts and their replacement by Bichat's tissues}

Animal experiment, to distinguish what portions of an animal were sensitive;

Applying reagents to organs, such as water (maceration) to soak tissues apart, and letting them decay under observation;

Dissections and autopsies; and

Observations on man in health and disease. ${ }^{83}$

None of these techniques was new. The relevance of animal experiment can only be understood by harking back to Aristotle. He believed, on theoretical grounds, that any sensation could be generated only in the appropriate Homoeomerous Part. ${ }^{84}$ Thus if it could be shown that one part of the body was in some way sensitive, and another not, the first must include some of the appropriate Part, and the second not. Observations could be made in experimental animals, or, when disease or injury offered opportunity, in man.

Maceration in water, or the use of various reagents, or his own sense of taste, or even digestion in his own stomach ${ }^{85}$ assisted Bichat's efforts to bring about separation of portions of one tissue from another more convincingly than anyone had done before. It was already known that maceration in water (or, especially for bones, acid treatment) could reveal a meshwork within various organs, presumed to be "cellular" tissue. His zeal for autopsies was remarkable: upwards of 600 bodies in one winter. ${ }^{86}$ It speaks perhaps of a certain desperation, since the mechanical separation he hoped for is largely unattainable, and certainly so without microscopy.

There is a certain two-dimensional quality about the concept of a "tissue" which is a legacy from its original derivation: a surface, not a solid. "Cellular tissue", as Haller fully recognized, condenses to form membranes, and inflammatory processes can spread along membranous surfaces; Bichat wrote a notable treatise on membranes and their pathology, dealing with the tissue he had inherited from his predecessors, before he described his set of tissues; but his tissues are conspicuously three-dimensional, such as muscle and bone. In a sense, the whole patient was regarded as two-dimensional until Bichat's time. Reiser describes how during the seventeenth and eighteenth centuries the physician's physical contact with the patient was usually limited to feeling the pulse, a situation which he indicates was not unknown even later on, but which yielded to the development of physical examination initiated by Auenbrugger and Laennec. ${ }^{87}$ Reiser is of course thinking of medicine and not of surgery nor of obstetrics.

The view that tissues are two-dimensional has some specious attraction even to the present day; Foucault as a rule refers to tissues as two-dimensional areas, ${ }^{88}$ in contrast to

${ }^{83}$ Bichat, op. cit., note 1 above, Préface.

${ }^{84}$ Op. cit., note 13 above.

${ }^{85}$ Xavier Bichat, Traité d'anatomie descriptive, 5 vols., Paris, Gabon et Cie. \& Brosson, 1801, vol. 1, p. 221, reports that veal nervous ganglia taste different from the nerves themselves, and p. 71 describes digestion in his own stomach as a method.

${ }^{86}$ Ibid., vol. 3, p. xxiv, reports this number of autopsies, and this part of the work was written not by Bichat himself but by his disciple Buisson. The figure of 600 is a little less than the 700-800 examined annually by the whole staff of Virchow`s Pathological Institute at Berlin (R. Virchow, Cellular pathology, transl. from 2nd edition by F. Chance, London, Churchill, 1860, p. xv) and may also be compared with John Hunter's claim to have dissected "some thousands" of human subjects by 1781 when he was about 53 (George Qvist, John Hunter, London, Heinemann, 1981, p. xi), and Rokitansky`s 30,000 autopsies during his 50-year career (E.B. Krumbhaar, Pathology, Clio Medica series, New York, Paul Hoeber, 1937, p. 90).

${ }^{87}$ S. J. Reiser, Medicine and the reign of technology, Cambridge University Press, 1978, ch. 1.

${ }^{8 x}$ Foucault, op. cit., note 60 above, p. xviii, 128: "reduce the organic volumes to great, homogeneous, tissual surfaces ..." [my italics]; p. 136 where "the medical gaze . . directed upon the two-dimensional areas of tissues 


\section{John M. Forrester}

the three-dimensional organs of the body. Foucault points out how in a similar way nosological studies up to this time deployed knowledge in tables and also on the "flat surface of perpetual simultaneity". ${ }^{89}$ He displays a certain preoccupation with the metaphor of the gaze (le regard); the gaze beholds surfaces, and is an abstraction from the reality of human vision, which when linked with exploring fingers and provided with the various mechanisms of depth perception can contribute to the contemplation of threedimensional reality. According to Foucault, Bichat "had a clinician's eye, because he gives an absolute epistemological privilege to the surface gaze". In fact he had significantly more than this contemplative clinician's eye; he had the fingers of a surgeon and morbid anatomist, and, as his description of his own methods confirms, thought about tissues in three dimensions, not two. So for that matter did his predecessor Bordeu, who described connective tissue as an organ, rather than as a tissue. ${ }^{90}$ Foucault does come to state unequivocally that the medical gaze at this time "is now endowed with a plurisensorial structure"; touch and hearing join in. ${ }^{91}$

From his predecessors Bichat inherited the first in time of his set of tissues, and a versatile and variable one too; it overlaps with mucous tissue and serous tissue in his set. He also inherited the most potent application for tissues as a concept: the application to pathology. He acknowledged his debt for this to his teacher Pinel, and Keel has traced it further back, to John Hunter in particular. ${ }^{92}$

\section{BICHAT'S SET OF TISSUES}

1. Cellular (i.e. areolar connective)

2. Nervous, of animal life

3. Nervous, of organic life

4. Arterial

5. Venous

6. Exhalant vessels

7. Absorbant vessels (i.e. lymphatics)
8. Bone
9. Bone marrow
15. Mucous
16. Serous
17. Synovia
10. Cartilage
18. Glandular
12. Fibrocartilage
19. Dermis
13. Muscular, of animal life
20. Epidermis
14. Muscular, of organic life
21. Hair. ${ }^{93}$

and symptoms, must in order to reconcile them, itself move along a third dimension ..."- the third dimension appears to be a temporal one, not a spatial one.

"s9 Ibid., p. 6.

${ }^{90}$ De Bordeu, op. cit., note 61 above, sect. 1: "L'organe [my italics| cellulaire . . nourrit tous les organes, elle en fait la base, elle les lie les uns aux autres..." And Laennec was doing the same later: "every type of lesion always presents the same manifestations in all organs belonging to the same system, whatever the difference of form and function between the parts (i.e. organs, as the word is normally employed) into the composition of which these organs enter" (cited by Rather, op. cit., note 29 above, p. 60).

"'Foucault, op. cit., note 60 above, p. 164.

92 Othmar Keel, 'La pathologie tissulaire de John Hunter', Gesnerus 1980, 37: 47-61. The effacing of this trail was noted in Boisseau's notice of Bichat in Bichat's Anatomie pathologique, dernier cours de Xavier Bichat, d'après un manuscrit autographe de P.-A. Béclard, avec un notice . . par F.-G. Boisseau. Paris, J.-B. Baillière, 1825, p. xiii: "La fière Angleterre suit aussi, mais de loin, les pas du Français qui a fait oublier Brown, Darwin (sc. Erasmus), Goodwin et même Hunter." But on the other side of the Channel, Craigie (David Craigie, Elements of general and pathological anatomy, Edinburgh, Adam Black, 1828, p. viii) specifies Hunter, Carmichael Smyth, Bichat, Thomson and Béclard as recognizing the advantages of a pat'oology based on tissues.

${ }^{93}$ Bichat, op. cit., note 1 above, p. Ixxix. On epidermis: vol. 2, p. 757, mentions that it could be soaked off from the underlying layers, and so was probably the horny layer of the epidermis, rather than the whole layer as now microscopically identifiable. 
First in the set is the original tissue, areolar connective tissue. Then Bichat's "nervous system of organic life" is approximately today's autonomic nervous system, regulating the organic functions recognized by Bichat as absorption, excretion, respiration and the like: features common to animals and vegetables. It is contrasted with the "nervous system of animal life" which governed voluntary movement and mediated sensation. Thus the "muscular system of animal life" is the voluntary muscle system, and the "muscular system of organic life" is smooth muscle. The distinction would later be extended even to bones; bones in general were "animal", but a few "organic": the hyoid and ossifications in the larynx, because connected with respiration, and the penile bone of certain animals, because concerned with reproduction. ${ }^{94}$ The distinction extended to disease as well: fits and convulsions were especially "animal", fevers "organic". Bichat also listed "exhalant vessels", which he believed were tiny vessels barely visible to the eye, emerging from arteries and opening into tissue spaces, allowing fluid to leave the vascular system which later returned by the absorbant or lymphatic system. ${ }^{95}$

Unlike some Homoeomerous Parts, none of his tissues are fluid. But solid though they are, the simile of a web or woven material is receding from view. Areolar connective tissue had long been seen as the most obvious part of a meshwork which condensed into membranes and ligaments, and permeated through bone and solid organs of all descriptions: a tissue indeed. But set this meshwork aside, and there is little or nothing "woven" about some of Bichat's twenty-one tissues; nervous tissue was notably lacking in the characteristic. Further, for Bichat a tissue could link in other tissues, and be a composite, say, of "cellular" tissue, blood vessels, and nerves. What distinguished it was partly such organization, along with colour, thickness, density and so on, and partly its properties. There was one he called "property of [all] tissue", which included stretchability and elasticity, and hardening or shrivelling up in response to various reagents; it is evident in "cellular" tissue, skin, and muscle, much less so in bone, cartilage and tendon. Further, each individual tissue should have its particular function. And in disease one tissue might be involved alone or predominantly: serous coats of organs inflamed, perhaps, but not their underlying organs.

Bichat's rather brief attempt to involve his tissues in embryogenesis was not very successful nor consistent. ${ }^{96}$ Just after conception, the fetus is a mucous mass, yet a composite of "general systems", homogeneous, yet about to become "tissu cellulaire", with nerves and vessels. His strength lay more in adult anatomy and pathology than in embryology.

The Homoeomerous Parts were discussed for some eighteen centuries. When commenting on his debts to his predecessors, Bichat made no mention of them. He was not

\footnotetext{
${ }^{44}$ C. Mayer, Ueber Histologie und eine neue Eintheilung der Gewebe des menschlichen Körpers, Bonn, Adolph Marcus, 1819, p. 12.

"His evidence is on p. 74 of vol. 1 of Anatomie générale (note 1, above). In essence, he felt that when fluid, or fat to be deposited in fatty tissue, passed out from the circulation, there must be tubes for it to pass along, and that he could just see them in some sites, but not (vol. 2, p. 249) in muscle. His belief was supported by the knowledge that from sweat glands fluid reaching them by the circulation reached the skin in ducts. (See ibid., vol. 1, p. 1 and 549; he regarded them as part of the "exhalant system".) W. R. Albury, "Experiment and explanation in the physiology of Bichat and Magendie', in Studies in the history of biology, vol. 1, Baltimore, Johns Hopkins University Press, 1977, on p. 49, points out that, as Bernard noted later, Bichat regarded the lymphatic system and the absorbant system as synonymous.

" Bichat, op. cit., note 1 above, vol. I, p. 1.
} 
a man to provide detailed citations; footnotes are barely present in the whole of his work. ${ }^{97}$ He wrote in haste: "when pressured for text, he used merely to compose parts of his book on whatever bits of paper fell to hand"; 98 he was conscious of the urgency of his originality 99 and perhaps too that his time was short. But he named those to whom he felt indebted, and those with whom he differed. The Preface to the first edition of his Recherches physiologiques sur la vie et la mort ${ }^{100}$ listed his predecessors-Aristotle, Buffon, Morgagni, Haller, Bordeu, but not Galen - and told his readers summarily to work out for themselves where his ideas came from, and which were his own. The Homoeomerous Parts were evidently quite invisible to him: an obsolete minor feature of the Galenic tradition.

So tracing any relation between the Parts and his tissues was a task not for him, but only for his biographers. Huard mentions it, ${ }^{101}$ and Haigh appositely remarks that "the resemblance between those classical concepts of the simple or homogeneous bodily parts and Bichat's notion of the tissues is merely superficial."102 Even for Harvey, Homoeomerous Parts had degenerated into mere terms of descriptive anatomy. Bichat's tissues had to grow from different stock, and he himself saw their distinct functions as features crucial for their importance. He viewed Haller as a key figure here, who "a jeté les fondemens d'une science qui n'a de commun que le nom avec l'ancienne," 103 and he believed that a tissue with its function was a biological element which only death could resolve into simpler components: a work of nature, and no artefact of science; something much more than a descriptive device of anatomists. ${ }^{104}$ Not that Homoeomerous Parts began as mere descriptive devices; but that was the guise of their old age.

The fate of Bichat's tissues was not so different. One of the rocks on which they also later foundered was lack of concordance about their number and identification. The tissue was soon "displaced in its role as the ultimate unit of life by the cell"; its decline is another story. ${ }^{105}$

\footnotetext{
${ }^{97}$ Vol. 4 of his Traité d'anatomie descriptive (note 85 above) shows some, but was not in the end his own work; his cousin Buisson completed this volume.

${ }^{98}$ Elizabeth Haigh, Xavier Bichat and the medical theory of the eighteenth century, Medical History Supplement no. 4, London, Wellcome Institute for the History of Medicine, 1984, p. 12.

${ }_{99}$ "The study of systems [more or less synonymous with tissues, with the emphasis particularly on function] barely existed before my work"-Bichat, op. cit., note 85 above, p. xiii.

${ }^{I(x)}$ Paris, Brosson, Gabon, 1800.

${ }^{101}$ Pierre Huard (ed.), Biographies médicales et scientifiques. XVIIIème siècle, Paris, Editions Roger da Costa, 1972. The Postface to Bichat's biography here is by Huard himself, and briefly specifies the contributions of Aristotle, Fallopius and others to discussion of the Homoeomerous Parts.

${ }_{102}$ Elizabeth Haigh, op. cit., note 98 above, p. 119.

${ }^{10.3}$ Bichat, op. cit., note 85 above, p. vii.

104 Bichat, op. cit., note 1 above, p. Ixxx.

${ }^{105}$ See for example Haigh, op. cit., note 98 above, especially ch. 8, 'After Bichat'.
} 